\title{
HUBUNGAN KARAKTERISTIK WIRAUSAHA DENGAN KEBERHASILAN USAHATANI HORTIKULTURA
}

(Kasus pada Petani Hortikulura di Kecamatan Lembang Kabupaten Bandung Barat)

\section{THE RELATIONSHIP BETWEEN ENTREPRENEURIAL CHARACTERISTICS AND THE SUCCESS OF HORTICULTURE FARMING}

(Case in Horticulture Farmers in Cibodas Village, Lembang District, West Bandung Regency)

\author{
Gema Wibawa Mukti*, Rani Andriani Budi Kusumo, Yosini Deliana \\ Program Studi Agribisnis, Fakultas Pertanian, Universitas Padjadjaran \\ *Email: gema.wibawa@unpad.ac.id \\ (Diterima 23-03-2020; Disetujui 20-05-2020)
}

\begin{abstract}
ABSTRAK
Tujuan dari penelitian ini adalah mengetahui bagaimana hubungan karakteristik wirausaha terhadap keberhasilan usahatani Petani Hortikultura di Kecamatan Lembang, Kabupatan Bandung Barat. Penelitian ini menggunakan desain kuantitatif dengan metode survey deskriptif. Sampel penelitian diambil dengan dengan metode probability sampling. Analisis data dilakukan secara statistik deskriptif dan menggunakan alat analisis korelasi Rank Spearman. Hasil penelitian menunjukkan, rata-rata sampel petani adalah laki-laki, dalam usia produktif, telah menerima program wajib belajar 9 tahun,dan memiliki luas lahan rata-rata 417,34 Tumbak. Karakteristik Wirausaha yang dimiliki oleh para petani termasuk dalam kriteria "Baik" dengan presentase $77.05 \%$, Keberhasilan Usahatani termasuk dalam kriteria "Baik" dengan presentase $77.2 \%$, dan Hasil penelitian menunjukkan terdapat korelasi positif pada semua karakteristik.
\end{abstract}

Kata kunci: Karakteristik Wirausaha, Keberhasilan Usahatani, Petani Muda

\begin{abstract}
The purpose of this study was to find out how the relationship between entrepreneurial characteristics and the success of Horticulture Farmers in Cibodas Village, Lembang District, West Bandung Regency. This research uses quantitative design with descriptive survey method. The research sample was taken by probability sampling method. Data analysis was carried out descriptively statistically and using Rank Spearman correlation analysis tools. The results showed that the average sample of farmers was male, in productive age, had received a 9-year compulsory education program, and had a business scale of 417.34 Tumbak. Entrepreneurial characteristics possessed by farmers are included in the criteria of "Good" with a percentage of 77.05\%, Farming success is included in the criteria of "Good" with a percentage of $77.2 \%$, and the results of the study show there is a positive correlation on all characteristics.
\end{abstract}

Keywords: Entrepreneurial Characteristics, Young Farmers, Success Farming

\section{PENDAHULUAN}

\author{
Semenjak \\ Adam \\ Smith \\ memperkenalkan teori ekonomi klasik
}

hingga Joseph Schumpeter memperkenal- kan konsep pertumbuhan ekonomi, kewirausaan memiliki peranan penting dalam pembangunan ekonomi suatu negara (Wennekers et al, 2010). 


\section{HUBUNGAN KARAKTERISTIK WIRAUSAHA DENGAN KEBERHASILAN USAHATANI \\ HORTIKULTURA \\ Gema Wibawa Mukti, Rani Andriani Budi Kusumo, Yosini Deliana}

Wennekers dan Thurik (1999)

menjelaskan bahwa kewirausahaan

merupakan faktor utama yang mempengaruhi pergerakan ekonomi dengan memperkenalkan inovasi, menyediakan pekerjaan, meningkatkan persaingan dan kesejahteraan masyarakat. Pertumbuhan ekonomi sangat tergantung kepada kesiapan dan kesediaan setiap individu di negara atau wilayah tersebut untuk memulai bisnis dan mengembangkan bisnis tersebut hingga sukses (Brandstätter, 2011; Thurik, 2008). Kewirausahaan memiliki peranan yang penting dalam pertumbuhan ekonomi suatu bangsa. Dalam era industri 4.0 (menuju 5.0), setiap orang harus memiliki kemampuan berkompetisi, inovatif dan senantiasa berorientasi pada perubahan. Persaingan yang ketat pada era globalisasi tentunya memerlukan karakteristik kewirausahaan yang kompetitif pula.

Persaingan terjadi dalam setiap sendi kehidupan ekonomi, termasuk sektor pertanian di dalam nya. Petani yang memiliki kinerja yang unggul dapat bertahan dan berkembang di dalam industri pertanian (food). Bagi seorang petani, karakteristik kewirausahaan merupakan sifat atau perilaku yang dapat menggerakkan faktor "bisnis" lainnya.
Petani yang memiliki karakter wirausaha akan menggunakan keahlian nya tersebut untuk mengelola modal dan tanah dengan baik, serta mampu untuk beradaptasi dengan perubahan alam dan lingkungan sekitar. Kewirausahaan tidak dapat dipisahkan dari pertanian, petani serta aktivitas usahataninya. Petani yang memiliki karakteristik kewirausahaan yang kuat akan memiliki kinerja usaha yang baik pula. Hal ini akan berdampak pada keberhasilan usahatani dari petani tersebut. Keberhasilan usaha menurut Chittithaworn, et al (2011) dapat diukur dari kelangsungan hidup usaha, perolehan laba, pertumbuhan penjualan, jumlah pekerja, perasaan bahagia variable lain yang terkait dengan keberhasilan usahatani.

Keberhasilan atau kesuksesan tergantung kepada usaha atau effort kita sendiri dalam berproses menuju kepada keberhasilan tersebut. Karakter diri menjadi satu faktor penting yang dapat mendukung individu tersebut untuk meraih keberhasilan dalam sebuah aktivitas usaha atau bisnis. Bisnis dalam bidang pertanian di Indonesia masih erat kaitan nya dengan aktivitas on farm. Fenomena saat ini memperlihatkan bahwa jumlah petani semakin berkurang. Data Badan Pusat Statistik (2015) 
menunjukkan bahwa tenaga kerja di sektor pertanian menurun sebesar 3,13\%, atau sebanyak 1,22 juta petani. Penurunan jumlah petani di Indonesia menurut Jusuf Kalla (2019) disebabkan oleh beberapa faktor, yaitu lahan pertanian yang semakin menurun, kegagalan panen yang menyebabkan para petani enggan meneruskan penggarapan lahan, dan pendapatan yang diterima dari hasil panen rendah menyebabkan para petani lebih memilih bekerja di sebuah industri. ${ }^{1}$

Meskipun jumlah petani semakin menurun, bisnis petani di beberapa sentra pertanian di Jawa Barat masih tetap bertahan bahkan dapat berkembang dengan baik. Eksistensi bisnis petani mengindikasikan adanya karakteristik khusus yang dimiliki oleh petani, sehingga mereka mampu bertahan dan mengembangkan usahanya. Salah satu sentra pertanian hortikultura di Jawa Barat adalah Kabupaten Bandung Barat. Pertanian di wilayah ini menjadi mata pencaharian utama bagi sebagian besar masyarakatnya. Pada tahun 2017, salah

\footnotetext{
${ }^{1}$ Dian Kurniawan, “Wapres JK Ungkap Alasan Jumlah Pekerja Pertanian Terus Menurun”, diakses dari https://www.liputan6.com/bisnis/read/2346902/w apres-jk-ungkap-alasan-jumlah-pekerja-pertanianterus-menurun, pada tanggal 23 Januari 2019, pukul 10.01
}

satu petani asal Cibodas mendapat penghargaan prestisius tingkat internasional dari Food and Agriculture Organization (FAO) of The United Nations sebagai pelopor yang berhasil mengembangkan usaha pertanian hortikultura. Penghargaan tersebut didapat setelah mengalahkan ribuan petani dari berbagai negara.

Petani hortikultura di Kecamatan Lembang Kabupaten Bandung Barat telah memiliki pasar yang jelas bagi produk mereka, mulai dari pasar tradisional, pasar modern/pasar terstruktur dan pasar ekspor. Keberhasilan atau prestasi ini tidak terlepas dari karakter wirausaha (Chittithaworn et al, 2011). Karakter wirausaha petani hortikultura yang kuat mendorong petani untuk senantiasa bertahan dan berkembang dalam bisnis yang saat ini mereka geluti. Berdasarkan hal tersebut, maka penulis memutuskan untuk melihat hubungan antara karakteristik wirausaha terhadap keberhasilan usahatani petani hortikultura di Kecamatan Lembang Kabupaten Bandung Barat.

\section{METODE PENELITIAN}

Secara etimologi, karakteristik adalah ciri yang menjadi pembeda 


\section{HUBUNGAN KARAKTERISTIK WIRAUSAHA DENGAN KEBERHASILAN USAHATANI \\ HORTIKULTURA \\ Gema Wibawa Mukti, Rani Andriani Budi Kusumo, Yosini Deliana}

memiliki sifat sesuai dengan perwatakan tertentu, setiap individu memiliki karakter yang berbeda satu dengan yang lainnya, termasuk dalam menjadi wirausahawan. Wirausahawan sukses umumnya memiliki karakteristik yang tidak jauh berbeda, dalam menjalankan usahanya. Karakteristik wirausaha secara umum menggambarkan keunikan personal atau psikologi seseorang yang terdiri dari dimensi nilai sikap dan kebutuhan. David (1996) menjelaskan bahwa karakteristik yang dimiliki oleh seorang wirausaha meliputi inovatif, kreatif, adaptif, dinamis, memiliki kemampuan berintegrasi, mampu mengambil dan mengatasi risiko atas keputusan yang dibuat, integritas, dan mempunyai daya-juang yang kuat. Kewirausahaan merupakan kualitas atau sifat yang tetap terus menerus dan kekal yang dapat dijadikan ciri untuk mengidentifikasikan seorang pribadi, suatu objek, suatu kejadian, intergrasi atau sintesis dari sifat-sifat individual dalam bentuk suatu atau kesatuan dan kepribadian seseorang, dipertimbangkan dari titik pandangan etis dan moral. Sementara sikap kewirausahaan adalah sikap seseorang yang mempunyai keinginan yang tinggi dari kehidupan sehari-hari atau ciri-ciri sikap seorang wirausaha (Faisal, 2002).

\section{Tabel 1. Karakteristik Wirausaha Menurut Para Ahli Kewirausahaan}

\begin{tabular}{|c|c|c|}
\hline No. & Karakteristik Wirausaha & Sumber \\
\hline 1. & Tanggung Jawab & $\begin{array}{ll}\text { - } & \text { Scarborough dan Zimmerer (1996) } \\
\text { - } & \text { Meredith (2005) } \\
\text { - } & \text { Bygrave (2010) }\end{array}$ \\
\hline 2. & Keberanian Mengambil Resiko & $\begin{array}{l}\text { - Scarborough dan Zimmerer (1996) } \\
\text { - Meredith (2005) }\end{array}$ \\
\hline 3. & Percaya Diri & $\begin{array}{l}\text { - Scarborough dan Zimmerer (1996) } \\
\text { - } \quad \text { Meredith (2005) } \\
\text { - } \quad \text { Bygrave (2010) }\end{array}$ \\
\hline 4. & Menghendaki Umpan Balik & $\begin{array}{l}\text { - Scarborough dan Zimmerer (1996) } \\
\text { - Bygrave (2010) }\end{array}$ \\
\hline 5. & Semangat dan Kerja Keras & $\begin{array}{l}\text { - Scarborough dan Zimmerer (1996) } \\
\text { - Bygrave (2010) }\end{array}$ \\
\hline 6. & Berorientasi Masa Depan & $\begin{array}{l}\text { - Scarborough dan Zimmerer (1996) } \\
\text { - } \quad \text { Meredith (2005) } \\
\text { - } \quad \text { Bygrave (2010) }\end{array}$ \\
\hline 7. & Menghargai Prestasi & $\begin{array}{l}\text { - Scarborough dan Zimmerer (1996) } \\
\text { - Bygrave (2010) }\end{array}$ \\
\hline 8. & $\begin{array}{l}\text { Kemampuan } \\
\text { (Kepemimpinan) }\end{array}$ & $\begin{array}{l}\text { - Scarborough dan Zimmerer (1996) } \\
\text { - } \quad \text { Meredith (2005) } \\
\text { - } \quad \text { Bygrave (2010) }\end{array}$ \\
\hline 9. & Keorisinilan & - Meredith (2005) \\
\hline
\end{tabular}


Dari beberapa karakteristik yang dikemukakan beberapa ahli dalam Tabel 1 di atas, terdapat kesamaan dalam karakteristik wirausaha. Dalam penelitian ini, penulis menggunakan 4 karakteristik yang diungkapkan oleh ketiga ahli di atas. Karakteristik wirausaha yang menjadi kajian utama dalam penelitian ini adalah tanggung jawab, percaya diri, berorientasi ke masa depan, dan kemampuan organisasi (kepemimpinan). Haryadi (2003) mengungkapkan keberhasilan usaha biasanya dicirikan dengan membesarnya skala usaha yang dimilikinya. Hal tersebut dicirikan oleh volume produksi yang terus berkembang dan skala usaha yang semakin ekonomis. Meredith et al, (2005) menjelaskan bahwa keberhasilan usaha dapat terlihat dari kemampuan dalam menetapkan tujuan dari usaha yang dijalankan. Tujuan dari usaha dapat dilihat dari 2 sisi yakni, keuangan dan non keuangan. Keberhasilan dari sisi keuangan dapat dilihat dari pertumbuhan usaha dan keuntungan yang diperoleh. Sedangkan dari sisi non-keuangan dapat dilihat dari peningkatan kesejahteraan individu dan keluarga yang dirasakan, mampu menyediakan lapangan tenaga kerja, serta mampu meningkatkan kapasitas diri dan orang lain.
Objek dalam penelitian ini adalah karakteristik wirausaha petani dan korelasinya terhadap keberhasilan usahatani yang mereka jalankan. Subjek dalam penelitian ini adalah para petani yang bergerak dalam bidang hortikultura di Kecamatan Lembang Kecamatan Lembang, Kabupaten Bandung Barat. Penelitian ini menggunakan metode probability sampling dengan dimana responden memiliki peluang untuk dipilih (Sugiyono, 2017). Sampel yang digunakan pada penelitian ini berjumlah 50 responden dimana dalam penelitian korelasi, jumlah anggota sampel 10 kali dari jumlah variabel (independen dan dependen) yang diteliti (Sugiyono, 2017). Variabel yang digunakan dalam penelitian ini adalah variabel independen (tanggung jawab, kepercayaan diri, berorientasi ke masa depan, kepemimpinan) dan variabel dependen (keberhasilan usaha).

Teknis analisis yang digunakan pada penelitian ini adalah dengan menggunakan skala likert untuk melihat karakteristik wirausaha petani muda dan teknik analisis korelasi rank spearman. Analisis korelasi Rank Spearman merupakan salah satu alat uji statistika yang bertujuan untuk menguji hubungan antara variabel bebas (independent) dan 
variabel terikat (dependen) penelitian yang berbentuk ordinal. Analisis Rank Spearman biasanya disimbolkan dengan $r s$ atau $\rho$ (Sugiyono 2011). Rank Spearman dirumuskan secara sistematis adalah sebagai berikut:

$\rho_{x y}=1-\frac{6 \sum D^{2}}{n\left(n^{2}-1\right)}$

Keterangan:

$\rho_{x y} \quad=$ Koefisien korelasi

Tabel 2. Koefisien korelasi dan tingkat hubungannya

\begin{tabular}{ll}
\hline Koefisien korelasi & Tingkat Hubungan \\
\hline$<0,19$ & Sangat Lemah \\
$0,20-0,39$ & Lemah \\
$0,40-0,59$ & Sedang \\
$0,60-0,79$ & Kuat \\
$0,80-1,00$ & Sangat Kuat \\
\hline
\end{tabular}

$\mathrm{D} \quad=$ Difference (beda antar jenjang setiap subjek)

$\mathrm{n} \quad=$ Banyak responden

Untuk mengetahui besarnya hubungan antara kedua variabel dan menentukan berada didalam kriteria mana, digunakan koefisien korelasi. Sugiyono (2011) mengungkapkan koefisien korelasi dikategorikan menjadi 5 kategori.

Sumber: Statistika Untuk Penelitian (Sugiyono, 2011)

\section{HASIL DAN PEMBAHASAN}

Karakteristik Wirausaha Petani

A. Percaya Diri

Tabel 3. Rekapitulasi Tanggapan Petani Mengenai Percaya Diri

\begin{tabular}{cccc}
\hline Kategori & Frekuensi (f) & Persentase & Kriteria \\
\hline sangat setuju & 4 & $8 \%$ & \\
Setuju & $\mathbf{3 8}$ & $\mathbf{7 6 \%}$ & \\
Netral & 5 & $10 \%$ & Baik \\
tidak setuju & 2 & $4 \%$ & \\
sangat tidak setuju & 1 & $2 \%$ & \\
\hline Jumlah & 50 & $100.00 \%$ & \\
\hline
\end{tabular}

Tingkat percaya diri petani dalam menjalankan usahatani termasuk dalam kriteria baik (76\%). Responden menganggap bahwa pilihan kerja atau profesi sebagai petani adalah sesuatu yang logis bagi diri mereka saat ini. Mereka menganggap petani adalah profesi yang cocok bagi kehidupan mereka. Mereka telah terbiasa dengan lingkungan pertanian, selain itu responden juga menganggap bahwa bisnis pertanian adalah bisnis yang dapat memberikan penghidupan yang layak bagi mereka. Seperti halnya bidang bisnis lainnya, petani responden pun pernah mengalami kegagalan dalam usahatani. Kegagalan tersebut dikarenakan kurang nya pengalaman di awal-awal usaha mereka. Namun mereka terus berproses, selalu berusaha untuk menemukan solusi 
dari masalah yang mereka hadapi. Mereka percaya bahwa sebuah bisnis pasti akan mengalami fluktuasi.

Petani responden selalu mencari cara agar mereka tetap bisa melanjutkan usahanya, apabila produk yang mereka berikan tidak sesuai dengan permintaan pasar atau kuantitas yang diminta kurang para petani akan bekerja sama dengan petani lain yang memiliki produk yang sesuai dengan kriteria pasar. Dengan semangat yang dimiliki, petani merasa usaha yang mereka jalani akan terus berjalan dan terus berkembang.

B. Tanggung Jawab

Tabel 4. Rekapitulasi Tanggapan Petani Mengenai Tanggung Jawab

\begin{tabular}{cccc}
\hline Kategori & Frekuensi (f) & Persentase & Kriteria \\
\hline sangat setuju & 5 & $10 \%$ & \\
Setuju & $\mathbf{4 1}$ & $\mathbf{8 2 \%}$ & \\
Netral & 2 & $4 \%$ & Sangat Baik \\
tidak setuju & 2 & $4 \%$ & \\
sangat tidak setuju & 0 & $0 \%$ & \\
\hline Jumlah & 50 & $100.00 \%$ & \\
\hline
\end{tabular}

Perhitungan di atas memperlihatkan bahwa petani hortikultura memiliki tanggung jawab atau inisiatif yang sangat baik $(82 \%)$ dalam menjalankan pekerjaannya. Seseorang yang memiliki inisatif yang tinggi akan mampu menghasilkan suatu pemecahan masalah (Mardiyanti, 2008). Para petani hortikultura dalam menjalankan pekerjaannya memiliki tanggung jawab yang sangat baik, mereka tidak hanya diam dan menunggu para konsumen untuk datang, tetapi mereka aktif untuk mencari tahu celah pasar yang bisa dimasuki.

Petani juga menjalankan bisnisnya dengan maksimal untuk mendapatkan hasil yang mereka harapkan sebelumnya. Pertanian adalah bidang usaha yang memiliki tingkat risiko yang tinggi. Bisnis pertanian sangat tergantung pada faktor eksternal (cuaca, iklim, kondisi tanah), sehingga dapat dikatakan bahwa bisnis pertanian adalah bisnis yang memiliki risiko tinggi. Oleh karena itu, petani adalah pebisnis yang berani mengambil risiko tersebut, menghadapi sesuatu yang sulit mereka kendalikan. Dalam menjalankan usahanya, petani menganggap bahwa mencoba sesuatu hal yang baru dalam usahanya adalah sebuah keniscayaan dalam bisnis nya, apalagi dalam era industri 4.0 seperti saat ini. Petani responden berani mencoba sesuatu 
yang baru, namun tentu mereka tetap akan melakukan perhitungan sebelum melakukan hal tersebut. Mereka memahami bahwa mereka berani mengambil risiko untuk meraih tujuan, namun bukan berarti mereka berspekulasi akan hal ini.

\section{Orientasi Masa Depan}

Tabel 5. Rekapitulasi Tanggapan Petani Mengenai Orientasi Masa Depan

\begin{tabular}{cccc}
\hline Kategori & Frekuensi (f) & Persentase & Kriteria \\
\hline sangat setuju & 4 & $8 \%$ & \\
Setuju & $\mathbf{3 2}$ & $\mathbf{6 4 \%}$ & \\
Netral & 6 & $12 \%$ & Baik \\
tidak setuju & 8 & $16 \%$ & \\
sangat tidak setuju & 0 & $0 \%$ & \\
\hline Jumlah & 50 & $100.00 \%$ & \\
\hline
\end{tabular}

Berdasarkan perhitungan pada

Tabel 5, orientasi petani terhadap masa depan termasuk pada kriteria baik (64\%). Sebagian besar petani telah menggunakan Standar Operasional Prosedur (SOP) pada lahan mereka masing-masing. Petani responden melakukan ini dengan berbagai alasan, diantaranya adalah: (1) Sebagai respon atas perubahan pasar hortikultura yang menuntut kualitas produk yang baik dan seragam, dan (2) Meminimalisir kerugian yang mungkin terjadi dalam aktivitas usahatani.

Petani responden umumnya telah melakukan pengembangan jenis produk. Para petani mulai mengembangkan jenis tanaman yang mereka tanaman dan melakukan sistem pertanian polikultur dimana sistem ini dalam satu lahan terdapat beberapa tanaman yang ditanam. Produk yang dihasilkan oleh petani umumnya masih dijual secara segar, belum dikemas secara baik. Kemasannya disediakan oleh konsumen, namun umumnya petani tidak melakukan pengemasan. Secara umum petani masih fokus pada pengembangan usahatani di kebun (on farm), sedangkan untuk pasca panen dan pemasaran petani belum berminat untuk berinvestasi dalam subsistem tersebut.

\section{Kemampuan Organisasi}

(Kepemimpinan) 
Tabel 6. Rekapitulasi Tanggapan Petani Mengenai Kemampuan Organisasi (Kepemimpinan)

\begin{tabular}{cccc}
\hline Kategori & Frekuensi (f) & Persentase & Kriteria \\
\hline sangat setuju & 4 & $8 \%$ & \\
Setuju & $\mathbf{3 4}$ & $\mathbf{6 8 \%}$ & \\
Netral & 5 & $10 \%$ & Baik \\
tidak setuju & 7 & $14 \%$ & \\
sangat tidak setuju & 0 & $0 \%$ & \\
\hline Jumlah & 50 & $100.00 \%$ & \\
\hline
\end{tabular}

Berdasarkan perhitungan pada mereka melakukan kolaborasi untuk Tabel 6 diatas, terlihat bahwa petani memiliki kemampuan organisasi memenuhi kebutuhan pasar serta dengan (kepemimpinan) yang baik (68\%). Petani baiknya relasi ini para petani juga lebih responden rata-rata telah memiliki mengetahui info pasar yang disebarkan melalui whatsapp. Para petani pekerja di lahan dan di bagian pasca hortikultura juga sangat terbuka dengan panen (melakukan sorting, grading, dan packaging produk). Para petani memiliki hubungan yang baik dengan para pekerja.

Selain itu, para pekerja juga mendapatkan tambahan ilmu dan lebih berkembang. Selain hubungan baik dengan para informasi-informasi baru yang dating kepada diri mereka. Mereka selalu memilih informasi yang berguna bagi mereka dan tidak jarang mereka menerapkan nya dalam kegiatan pekerja, para petani hortikultura juga memiliki relasi yang cukup baik dengan usahatani mereka. petani hortikultura lainnya. Tidak jarang

\section{E. Keberhasilan Usahatani}

Tabel 7. Rekapitulasi Tanggapan Petani Mengenai Keberhasilan Usahatani

\begin{tabular}{cccc}
\hline Kategori & Frekuensi (f) & Persentase & Kriteria \\
\hline sangat setuju & 1 & $2 \%$ & \\
Setuju & $\mathbf{3 6}$ & $\mathbf{7 2 \%}$ & \\
Netral & 3 & $6 \%$ & Baik \\
tidak setuju & 10 & $20 \%$ & \\
sangat tidak setuju & 0 & $0 \%$ & \\
\hline Jumlah & 50 & $100.00 \%$ & \\
\hline
\end{tabular}




\section{HUBUNGAN KARAKTERISTIK WIRAUSAHA DENGAN KEBERHASILAN USAHATANI \\ HORTIKULTURA \\ Gema Wibawa Mukti, Rani Andriani Budi Kusumo, Yosini Deliana}

Pada Tabel 7 terlihat bahwa persentase keberhasilan usahatani petani responden termasuk pada kriteria yang baik (72\%). Petani responden mengungkapkan bahwa usaha yang mereka jalankan saat ini mengalami pertumbuhan, jenis tanaman yang mereka usahakan juga terus bertambah. Petani responden umumnya menanam 2-4 tanaman dalam lahan yang mereka usahakan. Keuntungan yang didapat juga mengalami peningkatan, para petani mengungkapkan pendapatan dari awal usaha hingga saat ini mengalami peningkatan, namun tidak jarang para petani mengalami pendapatan stagnan saat sedikitnya hasil panen atau permintaan yang sedikit. Namun, hal ini hanya terjadi pada waktu-waktu tertentu saja, dimana secara rata-rata per tahun pendapatan mereka cukup stabil.

Kesejahteraan yang dirasakan oleh para petani serta keluarga termasuk dalam kriteria baik. Para petani mengungkapkan bahwa hasil dari usahatani ini mampu memenuhi kebutuhan pribadi serta keluarga. Petani responden juga memiliki waktu kerja yang fleksibel, sehingga mereka tidak terbebani oleh waktu kerja. Usahatani yang dijalankan oleh petani hortikultura ini juga menjadi wadah penyedia lapangan bagi masyarakat sekitar. Penyerapan tenaga kerja dilakukan dibeberapa bagian, mulai dari hulu hingga hilir. Biasanya pekerja yang bekerja pada bagian budidaya merupakan pekerja paruh waktu yang bekerja dari pagi hingga menjelang makan siang. Para pekerja di bagian pasca panen akan memulai pekerjaannya dari jam 3 sore hingga malam tergantung dari kuantitas permintaan konsumen. Para pekerja juga terus berkembang, dimana mereka selalu mendapatkan "update" pengetahuan yang dibagikan oleh petani.

\section{Hubungan Karakteristik Wirausaha} Dengan Keberhasilan Usahatani

A. Hubungan Karakteristik Percaya
Diri Dengan Keberhasilan
Usahatani




\section{Tabel 8. Perhitungan Analisis Korelasi Rank Spearman Hubungan Karakteristik Wirausaha Percaya Diri dengan Keberhasilan Usahatani}

\section{Correlations}

\begin{tabular}{lll|r|r} 
& & Percaya Diri & \multicolumn{1}{c}{$\begin{array}{c}\text { Keberhasilan } \\
\text { Usaha }\end{array}$} \\
\hline \multirow{2}{*}{ Spearman's tho } & Percaya Diri & Correlation Coefficient & 1.000 & .758 \\
\cline { 3 - 5 } & & Sig. (2-tailed) &. & .002 \\
\cline { 2 - 5 } & $\mathrm{N}$ & 50 & 50 \\
\cline { 2 - 5 } & Keberhasilan Usaha & Correlation Coefficient & .758 & 1.000 \\
\cline { 2 - 5 } & Sig. (2-tailed) & .002 & 50 \\
\hline & $\mathrm{N}$ & 50 & 50 \\
\hline
\end{tabular}

Berdasarkan pada analisis korelasi antara karakter percaya diri dengan keberhasilan usaha, terlihat bahwa karakteristik wirausaha percaya diri dengan keberhasilan para petani memiliki hubungan yang kuat. Scarborough dan Zimmerer (2005) mengungkapkan bahwa dengan kepercayaaan diri, seorang individu terus berusaha mengembangkan strategi dan membuka berbagai peluang bagi dirinya. Hal tersebut sesuai dengan yang terjadi di daerah penelitian. Para petani hortikultura Kecamatan Lembang berusaha untuk melakukan investasi pada usaha yang mereka miliki, baik dari sisi hulu maupun hilir.

Para petani hortikultura Kecamatan Lembang memiliki rasa kebanggaan terhadap pekerjaan mereka sebagai petani, mereka melakukan pekerjaan ini dengan tenang sehingga tidak ada beban yang dihadapi. Kepercayaan diri yang dimiliki para petani ini membuat hasil yang mereka dapatkan juga maksimal. Selain itu para petani juga merasa bahwa pekerjaan yang mereka jalani sekarang mampu memberikan kebahagiaan serta kesejahteraan untuk individu maupun keluarga. Para petani merasa bahwa keuntungan yang didapatkan selama menjalani usahatani mampu memenuhi kebutuhan sehari-hari keluarga, baik itu kebutuhan primer, sekunder maupun tersier.

B. Hubungan Karakteristik Tanggung Jawab Dengan Keberhasilan Usahatani 
Tabel 9. Hubungan Karakteristik Wirausaha Tanggung Jawab dengan Keberhasilan Usahatani

\section{Correlations}

\begin{tabular}{lll|r|r} 
& & \multicolumn{1}{c}{$\begin{array}{c}\text { Tanggung } \\
\text { Jawab }\end{array}$} & $\begin{array}{c}\text { Keberhasilan } \\
\text { Usaha }\end{array}$ \\
\hline Spearman's tho & Tanggung Jawab & Correlation Coefficient & 1.000 & .604 \\
\cline { 3 - 5 } & & Sig. (2-tailed) &. & .004 \\
\cline { 2 - 5 } & $\mathrm{N}$ & 50 & 50 \\
\cline { 2 - 5 } & Keberhasilan Usaha & Correlation Coefficient & .604 & 1.000 \\
\cline { 2 - 5 } & Sig. (2-tailed) & .004 &. \\
\cline { 2 - 5 } & $\mathrm{N}$ & 50 & 50 \\
\hline
\end{tabular}

Berdasarkan perhitungan analisis korelasi Rank Spearman, karakteristik tanggung jawab memiliki hubungan yang kuat dengan keberhasilan usahatani. Petani muda di Kecamatan Lembang menjalankan usahanya dengan sungguhsungguh. Petani responden memahami bahwa bertani adalah keahlian dan pekerjaan mereka, sehingga mereka fokus pada pekerjaan nya tersebut. Petani di Kecamatan Lembang, khususnya petani muda sangat memahami bahwa mereka harus melayani konsumen dengan sebaikbaiknya, diantaranya adalah dengan memperhatikan kegiatan on-farm secara maksimal. Hal ini mereka lakukan agar dapat menghasilkan produk yang berkualitas sehingga dapat memberikan kepada konsumen yang sudah ada dan membuat konsumen lain menjadi tertarik untuk membeli produk mereka.

$$
\text { Petani responden selalu }
$$
memberikan perhatian penuh pada bisnisnya, terutama pada kegiatan budidaya tanaman. Mereka selalu memberikan arahan para pekerja di kebun agar selalu menerapkan praktik budidaya yang sesuai dengan SOP dan petunjuk teknis, sehingga produk yang dihasilkan dapat optimal, baik dari sisi kuantitas maupun kualitas. Kebanggaan menjadi petani mendorong mereka untuk professional dalam pekerjaan nya, memberikan tanggung jawab penuh terhadap apa yang mereka kerjakan. Petani responden percaya bahwa tanggung jawab merupakan salah satu kunci keberhasila usaha yang mereka jalankan saat ini. Hambatan dalam usaha selalu ada, namun mencari cara untuk meminimalisir risiko adalah sebuah keniscayaan yang harus selalu petani lakukan dalam aktivitas bisnisnya.

\section{Hubungan Karakteristik Orientasi} Masa Depan Dengan Keberhasilan

\section{Usahatani}




\section{Tabel 10. Hubungan Karakteristik Wirausaha Orientasi Masa Depan dengan Keberhasilan Usahatani}

\section{Correlations}

\begin{tabular}{lllr|r} 
& & & \multicolumn{1}{c}{$\begin{array}{c}\text { Orientasi } \\
\text { Masa Depan }\end{array}$} & $\begin{array}{c}\text { Keberhasilan } \\
\text { Usaha }\end{array}$ \\
\hline \multirow{2}{*}{ Spearman's rho } & Orientasi Masa Depan & Correlation Coefficient & 1.000 & .241 \\
\cline { 3 - 5 } & & Sig. (2-tailed) &. & .001 \\
\cline { 2 - 5 } & $\mathrm{N}$ & 50 & 50 \\
\cline { 2 - 5 } & Keberhasilan Usaha & Correlation Coefficient & .241 & 1.000 \\
\cline { 2 - 5 } & Sig. (2-tailed) & .001 & 50 \\
\cline { 2 - 5 } & $\mathrm{N}$ & 50 & 50 \\
\hline
\end{tabular}

Berdasarkan perhitungan analisis korelasi Rank Spearman, karakteristik orientasi masa depan memiliki hubungan yang lemah dengan keberhasilan usahatani. Umumnya petani responden lebih fokus pada kondisi usaha mereka saat ini, bagaimana menghasilkan produk yang berkualitas dan menghasilkan keuntungan dari usahanya mereka tersebut. Petani responden sebagian besar masih berpikiran pragmatis (namun juga logis), dimana mereka mencoba untuk tidak mengalami kerugian dalam usaha nya saat ini. Mereka belum berpikir tentang investasi bagi pengembangan usahanya. Sebagai contoh mereka menerapkan teknologi irigasi di lahan nya semata-mata agar pengairan menjadi lebih mudah. Umumnya mereka belum memahami bahwa dalam jangka panjang hal tersebut dapat membuat pengairan lebih efisien, sehingga dapat menekan biaya produksi.
Petani responden umumnya melakukan sistem tanam polikultur untuk mengoptimalkan lahan yang mereka miliki. Mereka beranggapan bahwa dalam berusahatani harus memiliki beberapa sumber pendapatan, tidak hanya mengandalkan dari satu komoditas saja. Sehingga mereka menanam berbagai komoditas untuk mengantisipasi apabila satu jenis tanaman mengalami kerugian, dapat ditutup oleh keuntungan dari komoditas lainnya. Selain itu, petani melakukan sistem tanam polikultur untuk mengurangi risiko hama yang dapat menyerang tanaman mereka. Hingga saat ini belum melakukan investasi jangka panjang, seperti misalnya mengembangkan tanaman baru atau mencoba untuk membuka pasar yang baru. Petani responden fokus pada pemenuhan kebutuhan pasar yang ada saat ini, karena hal tersebut adalah sebuah "ikhtiar" logis yang dapat mereka lakukan. 


\section{HUBUNGAN KARAKTERISTIK WIRAUSAHA DENGAN KEBERHASILAN USAHATANI \\ HORTIKULTURA \\ Gema Wibawa Mukti, Rani Andriani Budi Kusumo, Yosini Deliana}

"Pidamel nu aya we heula ayeuna mah, da ieu ge tos masihan kauntungan anu sae. Abdi teu acan kaemutan nyobian anu sanes mah, kumargi pasarna oge da teu acan jelas, sareng modal masih terbatas. Tapi engke mah pasti hoyong langkung majeng deui usaha sayur teh"

(Kerjakan yang ada sekarang saja, karena ini juga sudah memberikan keuntungan yang bagus. Saya belum terpikir untuk mencoba yang lain karena pasarnya juga belum jelas dan untuk saat ini modal masih terbatas juga. Tapi ke depan saya juga pasti ingin lebih maju lagi dalam usaha ini) (Deni, petani sayur)

Saat ini petani telah menerapkan SOP di kebun mereka. Mereka

beranggapan bahwa penggunaan SOP mulai dari penanaman hingga pasca panen akan memberikan hasil yang maksimal. Sehingga memberikan kepuasan kepada konsumen yang telah membeli produk dari petani. Dengan kepuasan yang didapatkan, konsumen yakin untuk melanjutkan pembelian dan menambah kuantitas pada pembelian selanjutnya (Memiliki orientasi masa depan).

D. Hubungan Kemampuan Karakteristik (Kepemimpinan) Organisasi Keberhasilan Usahatani Dengan

Tabel 10. Hubungan Karakteristik Wirausaha Kemampuan Organisasi (Kepemimpinan) dengan Keberhasilan Usahatani

Correlations

\begin{tabular}{|c|c|c|c|c|}
\hline & & & $\begin{array}{c}\text { Kemampuan } \\
\text { Organisasi }\end{array}$ & $\begin{array}{c}\text { Keberhasilan } \\
\text { Usaha }\end{array}$ \\
\hline \multirow[t]{6}{*}{ Spearman's rho } & \multirow[t]{3}{*}{ Kemampuan Organisasi } & Correlation Coefficient & 1.000 & .088 \\
\hline & & Sig. (2-tailed) & . & .002 \\
\hline & & $N$ & 50 & 50 \\
\hline & \multirow[t]{3}{*}{ Keberhasilan Usaha } & Correlation Coefficient & .088 & 1.000 \\
\hline & & Sig. (2-tailed) & .002 & . \\
\hline & & $\mathrm{N}$ & 50 & 50 \\
\hline
\end{tabular}

Berdasarkan perhitungan analisis korelasi Rank Spearman, karakteristik wirausaha kemampuan organisasi (kepemimpinan) terhadap keberhasilan para petani hortikultura memiliki hubungan yang sangat kuat. Dalam aktivitas bisnisnya, petani responden mempunyai komunikasi yang baik dengan petani lain nya maupun dengan pekerja mereka di lahan. Aliran informasi terkait informasi pasar, harga dan teknis budidaya antar petani dengan petani dan juga petani dengan buruh tani) pekerja berjalan dengan baik. Informasi yang lancar membuat pekerja nyaman dalam bekerja, karena mereka merasa diberikan 
kepercayaan penuh dalam mengelola kebun. Pekerja juga tidak mengalami kesulitan dalam bekerja karena sebelumnya mereka telah diberikan SOP yang jelas sehingga mereka bekerja dengan mengikuti SOP tersebut.

Petani juga senantiasa menjaga komunikasi dengan petani lain nya. Ketersediaan teknologi informasi (jaringan seluler dan Handphone) yang cukup memadai di Kecamatan Lembang membuat komunikasi antar petani menjadi lebih mudah dan cepat. Petanipetani muda ini senantiasa berkolaborasi dan bekerjasama dalam memasarkan produk nya. Mereka berpendapat bahwa memenuhi permintaan pasar seorang diri adalah sesuatu yang sulit untuk dilakukan, karena dinilai tidak efektif dan efisien. Petani-petani ini berkolaborasi agar permintaan konsumen dapat terpenuhi, baik dari sisi kuantitas maupun kualitas. Petani mengungkapkan bahwa supermarket (pasar) sangat memperhatikan service level, dimana apabila kuantitas yang diminta tidak terpenuhi maka supermarket tersebut akan mengurangi pre-order yang akan dilakukan kepada petani.

\section{KESIMPULAN DAN SARAN}

\section{Kesimpulan}

Penilaian karakter wirausaha hampir menyebar rata di semua kategori. Sebagian besar petani hortikultura di Kecamatan Lembang memiliki tingkat karakter wirausaha dalam kategori baik. Hasil penelitian memperlihatkan bahwa terdapat empat karakter wirausaha yang berhubungan signifikan dengan keberhasilan usahatani. Keempat karakter tersebut adalah percaya diri, tanggung jawab, orientasi masa depan, dan kemampuan organisasi (kepemimpinan). Keberhasilan usaha memiliki korelasi yang positif dengan karakter wirausaha yang dimiliki oleh petani.

\section{Saran}

Penguatan karakter wirausaha menjadi salah satu hal penting yang dapat dilakukan untuk mengembangkan bisnis pertanian di Indonesia, khususnya di wilayah Kabupaten Bandung Barat. Penelitian selanjutnya diharapkan dapat lebih memperdalam aspek penguatan karakteristik kewirausahaan, sehingga akan selalu tumbuh petani-petani muda, terutama dalam bidang hortikultura. Hal ini diharapkan dapat mengembangkan pertanian dimana petani-petani muda 
sebagai motor pembangunan pertanian di Indonesia.

\section{DAFTAR PUSTAKA}

Badan Pusat Statistik Indonesia. (2018). Statistik Indonesia Tahun 2018. Jakarta. Badan Pusat Statistik Republik Indonesia.

Brandstätter, H. (2011). Personality aspects of entrepreneurship: A look at five meta-analyses. Personality and Individual Differences, 51(3), 222-230.

https://doi.org/10.1016/j.paid.2010. 07.007 .

Burhanuddin. (2011). Mendorong Pertumbuhan Ekonomi Melalui Peningkatan Jumlah Wirausaha: Sebuah Kerangka Penelitian. Di dalam: Baga LM, Fariyanti A, Jahroh S, editor. Orange Book 2: Kewirausahaan dan Daya Saing Agribisnis. Bogor (ID): IPB Press. Hlm1-13.

Chittithaworn, C., Islam, M.A. and Yusuf, D.H.M. (2011). Factors Affecting Business Success of Small \& Medium Enterprises (SMEs) in Thailand. Journal Asian Social Science, 7(5): 180-190.

Gitosardjoni, S.S. (2013). Wirausaha Berbasis Islam \& Kebudayaan, Jakarta: Pustaka Bisnis Indonesia.

Hardono, M. (2008). Intisari Manajemen Keuangan. Jakarta: Grasindo.

Herawaty. (2016). Wirausaha Muda dalam Peningkatan Pembangunan Pertanian. Agrica Ekstensia, 10 (2): 81-87.

Hismadiyani D., Fatimah, S., Firmansyah. (2017). Mengembangkan Jiwa Kewirausahaan Generasi Muda Melalui Pelatihan Penyusunan Rencana Usaha. Jurnal Mitra, 1 (1): 32-47.
Masykuri, A.A., \& Soesatyo, Yoyok. (2014). Analisis Perilaku Kewirausahaan Terhadap Keberhasilan Usaha Pada Usaha Kecil Menengah (UKM) Pengrajin Songkok di Kecamatan Bungah Kabupaten Gresik. Jurnal Pendidikan Ekonomi. 2(3): 1-19

Meredith G.G. (1996). Kewirausahaan: Teori dan Praktik. Jakarta: Pustaka Binaman Presindo.

Mulyadi. (1993). Akuntansi Manajemen, Konsep, Manfaat dan Rekayasa. Jakarta: PT Raja Grafindo Persada.

Nurayati P, Sarianti T, Daryanto HK, Muflikh YN. (2011). Analisis Pengaruh Karakteristik Kewirausahaan Terhadap Kinerja Wirausaha Pada Unit Usaha Kecil Menengah (UKM) Agroindustri di Kabupaten Bogor. Bogor (ID): Prosiding Seminar Penelitian Unggulan Departemen Agribisnis. Institut Pertanian Bogor.

Rachmat P., Priatna W.B., Burhannudin, Uswandi A. K., \& Fatika Y. H. (2011). Analisis Karakteristik Wirausaha Petani Padi (Studi Kasus Petani Gapoktan Wangun Jaya, Cianjur). Bogor: Prosiding Seminar Penelitian Unggulan Departemen Agribisnis 2011. Institut Pertanian Bogor.

Rahman, A. (2013). Pengaruh Karakteristik Individu, Motivasi dan Budaya Kerja Terhadap Kinerja Pegawai Pada Badan Keluarga Berencana dan Pemberdayaan Perempuan Kabupaten Donggala, Jurnal Katalogis, 1 (2):77-86.

Sander Wennekers \& Roy Thurik. (1999). Linking Enterpreneurship and Economic Growth. Small Bussiness Economics. 13 (1). Hal 27-56.

Setiyawati, Edwin C.N, Nugraha, Haris S., Ainuddin Ilham. (2013). Karakteristik Kewirausahaan dan 
Lingkungan Bisnis Sebagai Faktor Penentu Pertumbuhan Usaha (Studi IKM di Sentra Kerajinan Rotan Amuntai Kab. Hulu Sungai Utara, Provinsi Kalimantan Selatan). Jurnal Administrasi Bisnis, 2(1): 41-50.

Sugiyono. (2017). Metode Penelitian Kuantitatif, Kualitatif dan $R \& D$. Bandung: Alfabeta

Suryana. (2008). Kewirausahaan, Pedoman Praktis: Kiat dan Proses Menuju Sukses. Jakarta: Salemba Empat.

Thurik, R. (2015). The Effect of Entrepreneurial on National Activity Economic Growth, 24(3), 311-321. https://doi.org/10.1007/s1

Utami, Rizka Isnaeni. (2016). Analisis Hubungan Karakteristik Wirausaha dengan Keberhasilan Usaha pada Anggota Kelompok Wanita Tani Puspasari Kota Bogor [Skrispsi]. Bogor: Institut Pertanian Bogor.
Wennekers, S., van Stel, A., Carree, M. and Thurik, R. (2010), The Relationship between Entrepreneurship and Economic Development: Is It U-Shaped?. Foundations and Trends ${ }^{\circledR}$ in Entrepreneurship: Vol. 6: No. 3, pp 167-237. http://dx.doi.org/10.1561/03000000 23

William, D. Bygrave, DBA \& Zacharakis, P. Andrew. (2010). The portable MBA in entrepreneurship. Long Range Planning. Singapore: John Wiley \& Sons, Inc.

Zimmerer, Thomas W, Norman \&, Scarbrough. (2005). Kewirausahaan dan Manajemen Bisnis Kecil. Jakarta: Erlangga. 